\title{
HUMAN TRAFFICKING AND SURROGATE MOTHERHOOD: CHALLENGES
}

\author{
Viktor Checherskiy, \\ prosecutor of the Prosecutor General's Office, \\ Doctor of Juridical Science, Associate professor, \\ insomnia2012@ukr.net \\ orcid.org/0000-0002-4269-1247
}

\section{Summary}

Owing to modern scientific advances prospective parents, among other opportunities, enjoy the opportunity, which has not been available before. It consists in giving birth to a child by using another woman's reproductive capacity when the situation seems hardly improvable.

The paper examines surrogate motherhood as one of the reproductive methods through the prism of human trafficking. It aims at studying and differentiating such legal phenomena as the sale of human beings and surrogate motherhood, which is provided primarily on a paid-for basis, whose consequences (transferring irrevocably a child from one person to another), are externally similar.

The comparative legal and formal legal methods have been employed to provide a general description of international experience in regulating surrogate motherhood. Examples of absolutely opposite ways of pursuing state policy on the legalization of this type of reproductive methods in foreign countries are suggested: from a complete ban to legislative approval and even further simplification of the applying procedure.

It has been proved that there is no connection between acknowledgement of the legality of this procedure and the geographical location of states, the level of their economic development, the specifics of the legal system, and the like. It has been stated that none of the countries can be considered a universal example of solving these issues.

Based on the example of Ukrainian legislation, the author suggests distinguishing between the objective aspect of selling human beings and surrogate motherhood, which is provided, first of all, for a fee. It is emphasized that due to the peculiarities of reproductive technologies only a child should be the object of trade, not a person's gametes, zygote, embryo or fetus. When a child is sold, in view of the objective aspect, the child is illegally transferred from one person to another. In legal surrogate motherhood agreements the object of the agreement concluded between the surrogate mother and the future parents is not the child, but the service related to embryo implantation, pregnancy and childbirth, id est, a long process.

Based on criminal law, there have been modelled the peculiarities of surrogate motherhood and its assessment used in determining the signs of human trafficking largely depending on genetic relationship between a child and customers (potential parents), as well as a child and a surrogate mother.

The mental element making the distinction between surrogacy and the trafficking of newborns is described. It is emphasized that qualifying as "trafficking in human beings" necessitates the proof of direct intent to unlawfully «transfer» a child, primarily in return for a fee. 
It has been concluded that the legal regulation of surrogacy requires further improvement and consolidation at the legislative level. Investigators and prosecutors should investigate all the circumstances that were associated with the surrogacy methods applied in order to establish whether child trafficking occurred in each specific case.

Key words: human rights, reproductive rights, surrogate motherhood, surrogate mother, human trafficking, child trafficking

\section{Introduction}

Over the last decade reproductive technologies have become quite widespread. More and more childless people are referring to doctors for help to exercise their natural right to reproduction. Modern medicine offers several ways to solve the problem of childlessness, including in vitro fertilization. However, surrogacy remains the most controversial method.

This method allows separating the functions of a woman as a person who produces the female gamete and a person who gives birth to a child (Abdullah, 2019, p. 2).

The world community does not have common approaches to this type of reproductive technology. In some countries surrogacy is a criminal offense, in others it is a legal procedure. The study of foreign legislation testifies to the dynamism and diversity of legal regulation in this area. Some countries introduce additional stringent requirements for surrogacy, while others, on the contrary, simplify the grounds and conditions for its application.

Supporters and opponents of surrogacy often use the same facts, however they provide different arguments, trying to prove the need for liberalization or, on the contrary, the prohibition of surrogacy.

As a result, some call surrogacy a business or human trafficking, others a miracle or the last chance (Kopeltsiv-Levytska, 2019, p. 46). One of opponents' main arguments, in addition to the moral aspect, is that surrogacy is by nature trafficking in a newborn baby, which is recognized as one of the most serious crimes. For instance, F. M. Abdullah considers that pregnancy and giving birth to a child for another man or woman solely out of financial gain is immoral, illegal and insults the fundamental values of a democratic society such as the value of protecting women from exploitation and protecting the child born in this way (Abdullah, 2019, p. 4).
With this regard, it becomes necessary to study the relationship between human trafficking and surrogacy. This topic is of pressing concern to the post-Soviet countries, which have a fairly liberal legislative regulation on the use of reproductive technologies.

The purpose of the paper is to study and distinguish between such outwardly similar in consequences (irreversible transfer of the child from one person to another) legal phenomena as human trafficking and surrogacy which is primarily fee-based.

In addition, law enforcement agencies in several post-Soviet countries, including Georgia, Ukraine, and the Russian Federation, have recently launched criminal prosecutions for human trafficking of persons who organized or turned to surrogacy.

Hence, this study has not only a specific theoretical purpose, but also practical significance which consists in identifying and elucidating the differences between human trafficking and surrogacy.

In order to do this the author has resorted to the methodological potential available in legal science, first of all, comparative legal and formal legal methods, the methods of legal analysis and modelling.

Today there are many research papers that cover current issues of surrogacy and combating human trafficking. However, only in some of them the issue of human trafficking has been viewed through the prism of paid surrogacy, in particular, as a legal procedure. It has to be admitted that this topic was studied by such scholars as: I. Y. Veres, Ye. D. Kopeltsiv-Levytska, Fatma Mohamed Abdullah and others. However, their research is concerned with the substantiation of ranking paid surrogacy as child trafficking, rather than revealing the relationship between these acts which are outwardly similar. 


\section{The Legality of the Methods of Surrogate Motherhood}

The analysis of the international regulation proves that there is no connection between acknowledging the legality of surrogacy and the geographical position of countries, the level of their economic development, the specifics of the legal system, etcetera. Each country attempts to develop its own approach to solving the issue of legalization of surrogacy, taking into account its historical experience, development conditions, ideology and morality which prevail in society. In some countries this reproductive method is being liberalized (first of all, by expanding the grounds and range of entities that can use it), while in others, on the contrary, attempts are being made to limit it (including the protection of their own citizens from surrogate tourism).

Notably, surrogacy is prohibited under the laws of Bulgaria, Spain, Italy, Latvia, Lithuania, Malta, Norway, Germany, Switzerland and other countries (Präg, Mills, 2017).

In the Swiss Confederation the use of surrogacy is regulated at the constitutional level (Article 119 of the Federal Constitution of the Swiss Confederation, 1999). This country provided for the prohibition of surrogacy in the Constitution (Checherskyi, 2019, p. 82).

In France surrogacy is prohibited under the decree of 1991 passed by the Constitutional Council of the French Republic in compliance with which any agreement, even if it does not provide for remuneration, according to which a woman agrees to conceive, bear and give birth to a child and then abandon it, contradicts public policy, the principle of inviolability of the human body and the individual's personal status. The same provisions are enshrined in the Law of the French Republic «On Respect for the $\mathrm{Hu}$ man Body" adopted on July 29, 1994 (The Law of the French Republic «On Respect for the Human Body», 1994). Art. 16-7 of the French Civil Code states: "Any agreement concluded for the purpose of conceiving or bearing a child in favor of a third party is void» (Article 16-7 of the French Civil Code, 1804). The violation of these norms is punishable by imprisonment and fines (Article 227-12 of the French Criminal Code, 1992).

To the countries where surrogacy is allowed and where it is widely practiced belong: some states of Australia and the United States,
Great Britain, Canada, Portugal, the Russian Federation, Uganda, Ukraine, etc.

For example, in Israel, surrogacy is allowed only in cases when the surrogate mother has no genetic relationship with the child. The agreement must be approved by the committee consisting of social workers, doctors and religious figures. Although some monetary compensation is allowed, legal agreements must be altruistic and non-profit. All parties to the agreement must be citizens of Israel (Chernysheva, 2012, p. 209).

In Canada in 2004 The Assisted Human Reproduction Act was passed. It aims at regulating the use of assisted reproductive technologies and conducting the relevant research. This act allows surrogacy, establishes liability for violations of the legislation in this area and so on (The Assisted Human Reproduction Act, 2004).

In some countries, surrogacy is allowed only on a gratuitous basis, i. e. the surrogate mother cannot receive a financial reward for carrying and giving birth to a child (Australia, Belgium, Great Britain, Greece, Canada, etc.). In other countries, paid surrogacy is legally allowed (Armenia, Belarus, Georgia, Kazakhstan, Cyprus, Kyrgyzstan, Ukraine, etc.).

Another difference between countries in view of access to surrogacy is that many of them require both partners to provide their gametes when using surrogates, while others require gametes of only one biological parent. Thus, in the first case, single people, as a rule, cannot have a child using this method.

Article 146 of the Code of the Republic of Kazakhstan «On Public Health and Healthcare System» declares that a woman or a man who is not married has the right to resort to assisted reproductive methods and technologies if her (his) informed consent to medical intervention is available (Article 146 of the Code of the Republic of Kazakhstan «On Public Health and Healthcare System). However, governmental orders stipulate that only spouses have the right to surrogacy.

In the Russian Federation, a single woman has the right to make use of assisted reproductive technologies in case of availability of her voluntary informed consent to medical intervention (Article 55 of the Federal Law of the Russian Federation "On the Fundamentals of Protection of Public Health in the Russian Fed- 
eration»). Thus, single men are excluded from the list of subjects who are entitled to exercise this right.

However, in accordance with Art. 12 of the Law of the Republic of Armenia «On Reproductive Health and Reproductive Rights», a person entitled to use assisted reproductive technologies may also be one of the biological parents (Article 12 of the Law of the Republic of Armenia «On Reproductive Health and Reproductive Rights», 2012).

In international practice, there appear more and more precedents of giving birth to a child by a surrogate mother, not only for a married couple, but also single ones, under certain conditions. These include the death of their loved one, after which the genetic material remained, and the deceased person's will to use it, the unwillingness of single men to marry at the same time having a natural need for reproduction, etc (Checherskyi, 2019, p. 284).

Thus, K. Zakharova from the Russian Federation used donor eggs, her late son's cryopreserved sperm and the method of surrogacy in order to become a grandmother. (Svitnev, 2009).

A completely different approach has been introduced at the international and national levels regarding human trafficking, which is considered illegal and strict legal liability is envisaged for it. The prohibition of trafficking in human beings, in particular children, is a worldwide practice and is enshrined both in international law, such as the Convention on the Rights of the Child and the Optional Protocol to it dated 1 January 2000, and in national legislation.

\section{The Objective Aspect of the Distinction between Surrogate Motherhood and Human Trafficking Based on the Example of Ukrainian Legislation}

Legal regulation of surrogate motherhood in Ukraine is too general and needs significant improvement, as a result there are many loopholes and therefore opportunities for abuse.

Another situation occurs with regard to the regulation of combating human trafficking, where the legislation of Ukraine largely duplicates the requirements of the international acts and establishes criminal liability for this.
Notably, Art. 149 of the Criminal Code of Ukraine envisages liability for human trafficking, as well as the recruitment, transportation, transfer, harbouring or receipt of a person with the aim of exploitation through force, fraud, coercion or deception, blackmailing, material or other dependence of the victim, the victim's vulnerable condition, corruption of a third party that controls the victim in order to obtain consent for his / her exploitation.

Responsibility for recruiting, transporting, harbouring, transferring or receiving a minor or a juvenile arises regardless of whether such actions were committed with the use of coercion, abduction, deception, blackmail or the vulnerable condition of these persons or with the use of violence, or threat of violence, the use of official position, or by a person, on whom the victim was financially or otherwise dependent, or corruption of a third party that controls the victim with the purpose of obtaining his / her consent to exploitating a person (Article 149 of the Criminal Code of Ukraine, 2001).

Thus, in case of the trafficking of juveniles or minors, neither the form of the crime (recruitment, transportation, transfer, harbouring, transfer or receipt of a person) nor the method (using coercion, abduction, deception, blackmail, material or other dependence of the victim, his / her vulnerable condition, corruption of a third party who controls the victim), nor the purpose (the person's further exploitation) matters.

Similar provisions are found in the Law of Ukraine «On Combating Trafficking in Human Beings», which defines the trafficking of juveniles (minors) (The Law of Ukraine «On Combating Trafficking in Human Beings», 2011).

In view of the peculiarities of reproductive technologies, it must be emphasized that a child should be the object of such trade, not a person's gametes, zygote, embryo or fetus. If there are grounds, illegal agreements, when the latter are involved, may be qualified under other articles of criminal law.

Surrogacy necessitates the requirement lying in the fact that an angreement has to be concluded before implanting the embryo into a woman who assumes the responsibility of a surrogate mother.

Child trafficking involves the conclusion of an appropriate civil agreement regarding it 
at any stage, including fertilization, pregnancy, carrying of pregnancy and birth. However, in point of fact, this agreement contradicts the content and principles of national and international law, in particular those specified in the above-mentioned Law of Ukraine, i. e. is illegal. These can be purchase and sale agreements, mine-related and gift agreements or any other similar act accoding to which the child is illegally transferred from one person to another (Melnyk, Khavroniuk, 2019, p. 451).

When a child is trafficked, with respect to the objective aspect an illegal irrevocable transfer of the child from one person to another occurs.

The lawful transfer of a child from one person to another is not a criminal offence. In legal surrogacy agreements, the child is legally transferred because the object of such an agreement, which has been concluded between the surrogate mother and the intended parents, is not the child, but services related to embryo implantation, pregnancy, childbirth, i. e. a long process.

Admittedly, it is necessary to distinguish between paying for surrogacy services and child trafficking with receiving a remuneration fee.

In the first case, the talk is about providing paid services by a surrogate mother and the baby must be given (returned) to its parents, where the transfer of the child is a logical legal completion of the entire medical procedure related to ensuring reproductive rights. In the second case, the talk is about the initially illegal transfer of a child from one person to another for a fee, where the main purpose is the illegal transfer of the child, and the purpose is to obtain unlawful gain.

It should be stressed that receiving remuneration for surrogacy services should also be distinguished from receiving compensation for these services, which are only outwardly similar in content. At the same time, Ukrainian legislation does not particularly focus on this distinction. On the other hand, in some countries (for example, the United Kingdom) there is only the possibility of compensation for the inconvenience and expense incurred, otherwise the surrogacy service is illegal and may entail liability.

In view of the above said, taking into account the objective aspect, the mere fact of paying for surrogacy services cannot indicate child trafficking.

\section{Genetic Relationship and Surrogate Motherhood}

Modern medical science distinguishes two types of surrogacy:

- full or gestational surrogacy - transferring a human embryo conceived by spouses, wife and a donor, donors to a surrogate mother's body. In this case, the surrogate mother has no genetic relationship with the child;

- partial or gender surrogacy implies genetic relation to the baby because the surrogate mother's egg is used.

Taking into account Article 123 of the Family Code of Ukraine, the method of surrogate motherhood provides for the transfer of a human embryo conceived by spouses (genetic parents) to a surrogate mother's body. Hence, Ukrainian legislation establishes only one type o surrogacy, i. e. full (gestational) surrogacy (Article 123 of the Family Code of Ukraine, 2002). This condition is provided by the vast majority of other national lagislations.

It is reckoned that the prerequisite for legal paid surrogacy which does not contain any characteristics of human trafficking in view of the objective aspect, is the absence of genetic relationship between the child and the surrogate mother.

However, the evaluation of the actions of the surrogate mother, who was initially an egg donor, of other persons should be provided on the basis of all the circumstances of the case and does not exclude human trafficking.

The issue of obligatory genetic relationship between the child and the persons who resorted to the method of surrogacy requires a separate solution.

The ideal option is when both spouses are the biological parents of the unborn child. However, sometimes only one of the customers ordering this medical procedure has genetic relation with the child. Indeed, it is used by couples in which only the husband is fertile, single people who have used donor gametes, and so on.

Thus, in the absence of genetic relation between the child and both parents, there may be other types and combinations of artificial insemination, including the use of embryo or gamete donation, which in itself does not entail the illegality of surrogacy, refusal to acknowledge 
parenthood and the automatic establishing of the fact of human trafficking.

An exception is the case when such a newborn child is "sold" by genetic parents (one of them) to other persons. However, in this case, the situation is similar to the usual illegal sale of a baby, irrespective of the method of conception.

The current Ukrainian legislation does not define a clear procedure for using surrogate motherhood for the birth of a child who is not genetically related to either parent.

From our perspective, the combination of surrogacy and the use of only donated gametes is in fact a "hidden form of adoption" and is not related to the exercise of one's natural right to reproduction. However, while agreeing to the fact that the application of the methods themselves is illegal, it cannot be asserted that there is undoubtedly «child trafficking».

So, if a person has resorted to these hybrid methods because of reluctance to adopt a child (inter alia, for preventing future risks of property claims which can be imposed the adopted child's relatives, or the removal of the child by his / her parents, or for other objective or subjective reasons (quite often it is used for the purpose of concealing his /her own infertility), however, for the purpose of parenthood, then the chance of proving particularly the case of child trafficking in court is minimal. Moreover, in this case there is no agreement on the transfer of one's own child to another person (that is, the trade itself) since the child formally does not belong to a surrogate mother (who has no genetic relationship), by whom a newborn baby is transferred under the relevant legal agreement.

It has to be underlined that there are cases when pregnant women sell their children, falsifying documents for surrogacy. In this case, such actions should be classified as human trafficking.

To exemplify this, there can be mentioned an indictment against a citizen on charges of trafficking minors which was referred to court by Kyiv Local Prosecution Office in February 2021. Participating in a surrogacy program, she, contrary to the terms of the agreement, knowing for sure that she is the biological mother of a newborn baby, in order to receive 15 thousand dollars illegally gave it to foreign customers who were unaware of the fraud and believed that the baby was genetically connected with them.

\section{The Subjective Aspect of the Distinction between Surrogate Motherhood and Human Trafficking Based on the Example of Ukrainian legislation}

One of the main criteria in distinguishing between human trafficking and paid surrogacy is the subjective aspect.

The subjective aspect presupposes the presence of direct intent to illegally "alienate» the child, primarily for the sake of payment.

The offender must be aware that he is illegally transferring the child to third parties, including the fact of a fee-paying basis (for example, a surrogate mother realizes that she is a genetic mother, but sells it under a sham surrogacy agreement) or a surrogacy program is conducted with the purpose of further trafficking of the child (i. e. the birth of a child is not aimed at the emergence of parenthood in the situation with persons who have resorted to this method, primarily genetic parents, but at selling the child to persons who will involve him / her in the practice of begging, the use of the child's stem cells or organs, etc.

However, provided a person has used artificial insemination methods for the purpose of parenthood and paid for artificial insemination services, then, in our opinion, no human trafficking in these actions is identified.

Among the exceptions there are cases in which one of the genetic parents consciously renounces parenthood by transferring the child to another person for a fee. For example, a mother sells a newborn child, or one of the genetic parents refuses from a child and refuses to acknowledge her / his genetic parenthood in favor of another person for a certain fee. In this context, child trafficking occurs if the genetic mother (egg donor) when using surrogacy services deliberately received a payment not only for a fictitious marriage, but also for the "selling» her own child, i. e. a conscious act of trafficking in a newborn child.

It should be noted that no person, including a surrogate mother, officials who ensured the implementation of the surrogacy program, can be responsible for further actions of parents who made use of surrogacy, and their treatment of the child if such actions do not involve a common criminal intent to commit the crime. 


\section{Conclusions.}

Currently, at the international level, there is no consensus regarding the legality of using the surrogacy methods and their correlation with such a particularly serious crime as child trafficking. Nevertheless, none of the countries can be a universal example of solving this problem.

Issues that arise in the field of commercial surrogacy in Ukraine and other countries, the existing abuses in it are a substantial reason to improve the system and not to lead to banning this medical procedure.

Paid surrogate motherhood, whether acknowledged or not by the state as a crime, should be distinguished from trafficking of humans, including children. In view of both objective and subjective aspects, surrogacy significantly differs from human trafficking, and therefore these components must be investigated by law enforcement bodies in each case to accurately qualify the committed act.

Within the criminal justice aspect, it is necessary to prove the fact of deliberate violation by the subjects participating in the program, of the procedure and grounds for surrogacy with the purpose of further trafficking of newborns.

Investigators and prosecutors should study all the circumstances connected with the surrogacy methods, which were used, in order to determine whether child trafficking has occurred in each particular case.

\section{Bibliography:}

1. Кодекс Республики Казахстан о здоровье народа и системе здравоохранения. (2020). № 360VI. URL: https://online.zakon.kz/document/?doc_ id=34464437\#pos=74;-86.

2. Копельців-Левицька, Є. Д. (2019). Сурогатне материнство: торгівля дітьми чи послуга у сфері допоміжних репродуктивних технологій. Публічне право, 2, 45-49.

3. Кримінальний кодекс України. (2001): Закон України № 2341-III. URL: https://zakon.rada.gov.ua/laws/ show/2341-14.

4. Мельник, М. І., Хавронюк, М. І. (2019). Кримінальний кодекс України : наук.-практ. коментар./ К.: ВД «Данкор», 1384 c.

5. О репродуктивном здоровье и репродуктивных правах человека. (2002): Закон Республики Армения № 3P-474-H. URL: https://www.arlis.am/documentview. aspx?docid=63870.
6. Об основах охраны здоровья граждан в Российской Федерации. (2011): Федеральный Закон Российской Федерации № 323-Ф3. URL: http://www.consultant. ru/cons/cgi/online.cgi?from=325674-0\&rnd= 2819542E6C4EAFAFD5DD797694D95F49\&req=doc \&base $=$ LAW \& $=342243 \&$ REFDOC $=325674 \&$ REFBAS $\mathrm{E}=\mathrm{LAW} \# 2 \mathrm{pc} 1 \mathrm{mmozqzu}$.

7. Про протидію торгівлі людьми. (2011): Закон України № 3739-VI. URL: https://zakon.rada.gov.ua/laws/ show/3739-17\#Text.

8. Свитнев, К. Н. Жизнь после смерти. Юридические и этические аспекты посмертной репродукции. URL: http://svitnev.ru/speech/life_after_death.pdf.

9. Сімейний кодекс України. (2002): Закон України № 2947-III. URL: https://zakon.rada.gov.ua/laws/ show/2947-14.

10. Чернышева, Ю. А. (2012). Правовое регулирование суррогатного материнства в зарубежных странах. Грамота, 1 (15). Ч. 1. С. 209-211.

11. Чечерський, В. І. (2019). Закріплення права людини на репродукцію (відтворення) у законодавстві зарубіжних країни: порівняльно-правове дослідження. Порівняльно-аналітичне право, 5. С. 81-84.

12. Чечерський, В. І. (2019). Право на репродукцію (відтворення) у системі основоположних прав людини: конституційно-правове дослідження. : монографія. Херсон : Видавництво «ОЛДІ-ПЛЮС», 416 с.

13. Abdullah, F. M. (2019). Legal and Ethical Aspects beyond Commercial Surrogacy: Modern Form of Human Trafficking. Journal of Legal, Ethical and Regulatory Issues, 22 (S1), 1-7.

14. Assisted Human Reproduction Act. (2004). URL: https:// laws-lois.justice.gc.ca/PDF/A-13.4.pdf.

15. Code civil. (1804). URL: https://www.legifrance.gouv. $\mathrm{fr} /$ affichCodeArticle.do;jsessionid=9553F21AB14E 9F0DC96324B21F920BC1.tpdjo12v_3?idArticle=LEGI ARTI000006419302\&cidTexte $=$ LEGITEXT000006070 $721 \&$ dateTexte $=20100525$

16. Code penal. (1992). URL: https://www.legifrance.gouv. fr/affichCode.do;jsessionid=9553F21AB14E9F0DC963 24B21F920BC1.tpdj012v_3?idSectionTA=LEGISCTA00 $0006165320 \&$ cidTexte $=$ LEGITEXT000006070719\&d ateTexte $=20100525$

17. Patrick Präg, Melinda C. Mills. Assisted Reproductive Technology in Europe: Usage and Regulation in the Context of Cross-Border Reproductive Care. URL: https://link.springer.com/chapt er/10.1007/978-3-319-44667-7_14.

18. Relative au respect du corps. (1994). № 94-653. URL: https://www.legifrance.gouv.fr/affichTexte.do?cidText e=JORFTEXT000000549619\& fastPos $=2$ \& fastReqld $=2$ $078979333 \&$ categorieLien=cid \&oldAction=rechTexte \#LEGIARTI000006284446. 
19. Federal Constitution of the Swiss Confederation. (1999). URL: $\quad$ https://fedlex.data.admin.ch/filestore/fedlex. data.admin.ch/eli/cc/1999/404/20210101/en/pdf-a/ fedlex-data-admin-ch-eli-cc-1999-404-20210101en-pdf-a.pdf.

\section{References:}

1. Kodeks respubliki Kakhakhstan o zdorovye naroda $i$ sisteme zdravookhraneniya [Code of the Republic of Kazakhstan «On Public Health and Healthcare System»]. (2020). № 360-VI. Available from: https://online.zakon. kz/document/?doc_id=34464437\#pos=74;-86. [in Russian].

2. Kopeltsiv-Levytska, Ye. D. (2019). Surohatne materynstvo: torhivlia ditmy chy posluha u sferi dopomizhnykh reproduktyvnykh tekhnolohii [Surrogate pregnancy: child trafficking or service in the sphere of assisted reproductive technology] Publichne pravo, 2, 45-49. [in Ukrainian].

3. Kryminalnyi kodeks Ukrainy [Criminal code of Ukraine]. (2001). № 2341-III. Available from: https://zakon.rada. gov.ua/laws/show/2341-14. [in Ukrainian].

4. Melnyk, M.I., Khavroniuk, M.I. (2019). Kryminalnyi kodeks Ukrainy: nauk.-prakt. komentar [Criminal Code of Ukraine scientific and practical commentary]. K.: VD «Dankor», 1384 p. [in Ukrainian].

5. O reproduktivnom zdorovye i reproduktivnykh pravakh cheloveka [Law of the Republic of Armenia «On Reproductive Health and Human Reproductive Rights»]. (2002). № 3P-474-H. Available from: https://www.arlis. am/documentview.aspx?docid=63870. [in Russian].

6. Ob osnovakh okhrany zdorovia grazhdan $v$ Rossiyskoy Federatsii [Federal Law of the Russian Federation «On the basics of public health in the Russian Federation»]. (2011). № 323-Ф3. Available from: http://www. consultant.ru/cons/cgi/online.cgi?from $=325674$ 0\&rnd $=$ 2819542E6C4EAFAFD5DD797694D95F49\& $r$ eq $=$ doc $\&$ base $=$ LAW \& $n=342243 \&$ REFDOC $=325674 \&$ REFBASE=LAW\#2pc1mmozqzu. [in Russian].

7. Pro protydiiu torhivli liudmy [Law of Ukraine «On Combating Trafficking in Human Beings»]. (2011). № 3739-VI. Available from: https://zakon.rada.gov.ua/ laws/show/3739-17\#Text. [in Ukrainian].

8. Svitnev, K. N. Zhizn posle smerti. Yuridicheskiye i eticheskiye aspekty posmertnoy reproduktsii. [Life after death. Legal and ethical aspects of posthumous reproduction]. Available from: http://svitnev.ru/ speech/life_after_death.pdf. [in Russian].

9. Сімейний кодекс України [Family code of Ukraine] (2002). № 2947-III. Available from: https://zakon.rada. gov.ua/laws/show/2947-14. [in Ukrainian].
10. Chernysheva, Yu. A. (2012). Pravovoye regulirovaniye surrogatnogo materinstva $\mathrm{v}$ zarubezhnykh stranakh [Legal regulation of surrogate motherhood in foreign countries]. Gramota, 1 (15). Ch.1.P. 209-211. [in Russian].

11. Checherskyi, V.I. (2019). Zakriplennia prava liudyny na reproduktsiiu (vidtvorennia) u zakonodavstvi zarubizhnykh krainy: porivnialno-pravove doslidzhennia [Representation of human right to reproductive procreation in the legislation of foreign countries: a comparative legal research]. Porivnialno-analitychne pravo, 5. P. 81-84. [in Ukrainian].

12. Checherskyi, V. I. (2019). Pravo na reproduktsiiu (vidtvorennia) u systemi osnovopolozhnykh prav liudyny: konstytutsiino-pravove doslidzhennia [The right to reproduction (procreation) in the system of fundamental human rights: constitutional and legal research]. Manuscript. Kherson : Vydavnytstvo «OLDI-PLIuS», 416 p. [in Ukrainian].

13. Abdullah, F.M. (2019). Legal and Ethical Aspects beyond Commercial Surrogacy: Modern Form of Human Trafficking. Journal of Legal, Ethical and Regulatory Issues, 22 (S1), 1-7.

14. Assisted Human Reproduction Act. (2004). Available from: https://laws-lois.justice.gc.ca/PDF/A-13.4.pdf.

15. Code civil [Civil Code]. (1804). Available from: https:// www.legifrance.gouv.fr/affichCodeArticle.do;jsession id=9553F21AB14E9F0DC96324B21F920BC1.tpdjo1 $2 v \_3$ ?idArticle $=$ LEGIARTI000006419302 \&cidTexte $=$ LEGITEXT000006070721\&dateTexte $=20100525$. [in French].

16. Code penal [Criminal Code]. (1992).Available from: https:// www.legifrance.gouv.fr/affichCode.do;jsessionid=9553F 21AB14E9F0DC96324B21F920BC1.tpdjo12v_3?idSecti onTA=LEGISCTA000006165320\&cidTexte=LEGITEXT00 0006070719\&dateTexte=20100525. [in French].

17. Patrick Präg, Melinda C. Mills. Assisted Reproductive Technology in Europe: Usage and Regulation in the Context of Cross-Border Reproductive Care. Available from: https://link.springer.com/chapt er/10.1007/978-3-319-44667-7_14.

18. Relative au respect du corps [Relating to respect for the body]. (1994). № 94-653. Available from: https:// www.legifrance.gouv.fr/affichTexte.do? cidTexte=JORF TEXT000000549619\& fastPos $=2$ \& fastReqld $=2078979$ 333 \& categorieLien=cid \&oldAction=rechTexte\#LEGIA RTI000006284446. [in French].

19. Federal Constitution of the Swiss Confederation. (1999) Available from: https://fedlex.data.admin.ch/filestore/ fedlex.data.admin.ch/eli/cc/1999/404/20210101/ en/pdf-a/fedlex-data-admin-ch-eli-cc-1999-40420210101-en-pdf-a.pdf. 


\title{
ТОРГІВЛЯ ЛЮДЬМИ ТА СУРОГАТНЕ МАТЕРИНСТВО: ПРОБЛЕМНІ ПИТАННЯ
}

\author{
Віктор Чечерський, \\ прокурор Офісу Генерального прокурора, \\ доктор юридичних наук, доцент, \\ insomnia2012@ukr.net \\ orcid.org/0000-0002-4269-1247
}

\section{Анотація}

Сучасні наукові досягнення надали майбутнім батькам, серед іншого, можливість, яка не існувала до цього часу - народити дитину у майже безнадійній ситуащії за допомогою використання репродуктивних можливостей сторонньої жінки.

У статті розглядається сурогатне материнство, як одна з репродуктивних методик, через призму торгівлі людиною. Ії метою є дослідження та розмежування таких ззовні подібних за наслідками (у виді безповоротної передачі дитини від однієї особи до іншої) правових явищ, як торгівля людиною і сурогатне материнство, перш за все оплатне.

Із використанням порівняльно-правового та формально-юридичного методів надано загальну характеристику міжнародного досвіду регулювання сурогатного материнства. Наведено приклади абсолютно протилежної державної політики щодо легалізації цього виду репродуктивної методики у зарубіжних країнах: від повної заборони до законодавчого погодження та навіть подальшого спрощення процедури ії застосування.

Доведено, що не спостерігається будь-якого зв'язку між визнанням легальності цієї процедури і географічним розташуванням держав, рівнем ї економічного розвитку, специфікою правової системи тощо. Констатовано, що жодна з країн не може бути універсальним прикладом вирішення цієї проблематики.

На прикладі українського законодавства автором запропоновано розмежування об'єктивної сторони торгівлі людиною і сурогатним материнством, у першу чергу оплатним. Підкреслено, що враховуючи особливості репродуктивних технологій обєєтом торгівлі має бути дитина, а не гамети особи, зигота, ембріон чи плід. При торгівлі дитиною з обєктивної сторони відбувається незаконна безповоротна передача дитини від однієї особи до іншої. В законних угодах сурогатного материнства об'єктом договору, що укладається між сурогатною матір'ю і майбутніми батьками, $\epsilon$ не дитина, а послуги, повязані з імплантацією ембріона, виношуванням та народженням дитини, тобто тривалий процес.

3 погляду кримінального права змодельовано особливості сурогатного материнства та його оцінки при визначенні ознак торгівлі людьми залежно від генетичного споріднення між дитиною та замовниками (потенційними батьками), а також між дитиною і сурогатною матір'ю.

Надано характеристику суб'єктивній стороні, яка розмежовує сурогатне материнство та торгівлю новонародженою дитиною. Наголошено, що для кваліфікації «торгівля людиною» необхідним $є$ доведення прямого умислу на протиправне «відчуження» дитини, перш за все за оплату.

Зроблено висновок, що правове регулювання сурогатного материнства потребує подальшого удосконалення та закріплення саме на законодавчому рівні. Слідчі та прокурори повинні досліджувати всі обставини, що були пов'язані із застосованою методикою сурогатного материнства для того, щоб встановити чи мала місце торгівля дитиною у кожному конкретному випадку.

Ключові слова: права людини, репродуктивні права, право на репродуктивне відтворення, сурогатне материнство, сурогатна матір, торгівля людьми, торгівля дітьми 